\title{
Fathering Dalam Pengasuhan Anak Usia Dini Pada Keluarga Komunitas Pekerja Rumah Sakit Abdul Manap di Kota Jambi
}

\author{
Agustien Cahyaningrum \\ Universitas Islam Negri Sulthan Thaha Saifuddin, Jambi \\ Email:tieeen@gmail.com \\ Minnah El Widdah \\ Universitas Islam Negri Sulthan Thaha Saifuddin, Jambi \\ Email: elwiddah01@gmail.com \\ Yennizar $\mathbf{N}$. \\ Institut Agama Islam Nusantara Batang Hari, Jambi \\ Email:yenni.agus@gmail.com
}

\begin{abstract}
The important role of a father that lasts a lifetime in a child's life is to love, train and be an example. Father as the initial foundation that builds self-confidence in the environment. Fathering's study in early childhood parenting seeks to return the father's position to his nature as a leader. This study aims to determine the practice of fathering carried out by fathers in the community of hospital workers whose working hours tend to be abnormal so that it can become an obstacle in carrying out the ideal parenting process for their children. With a qualitative descriptive research methodology with a psychological approach, it is obtained data that the fathers in the family community of Abdul Manap Hospital workers in Jambi City have not fully understood the importance of the role of fathers (Fathering) in early childhood care, indicated by the results of interviews with 17 subjects measured by a scale The attitude of the father (Fathering Profile), the majority give answers "occasionally" and the results of the scores obtained by the all of subjects are at the level of "Average to Low", which is in the middle range tends to be low. The results of the study were analyzed through the opinions of experts, reinforced by explanations in the Al-Qur'an and the Hadith of the Prophet so that they become a new discourse for the contribution of early childhood education in the era of 4.0 where parents are required to educate children according to their era. The Platinum generation (Gen Z) with Millennial parents who are in the vortex of free information flow, have an open character, need space to talk and be heard. Fathers need insight and knowledge to be more involved in parenting. The lifelong practice of loving, training and modeling can be applied by increasing the intensity of the dialogue between father and son.
\end{abstract}

Keywords: Fathering; Parenting; Early Chlidhood 


\begin{abstract}
Abstrak
Peran penting seorang ayah yang berlangsung seumur hidup dalam kehidupan anak adalah mencintai, melatih dan menjadi teladan. Ayah sebagai peletak dasar awal yang membentuk kepercayaan diri terhadap lingkungan. Kajian Fathering dalam pengasuhan anak usia dini berupaya mengembalikan posisi ayah kepada fitrahnya sebagai seorang pemimpin. Penelitian ini bertujuan mengetahui praktek Fathering yang dilakukan oleh para ayah dalam keluarga komunitas pekerja Rumah Sakit yang memiliki jam kerja cenderung tidak normal sehingga dapat menjadi hambatan dalam melakukan proses pengasuhan yang ideal bagi anakanak mereka. Dengan metodologi penelitian Deskriptif Kualitatif dengan pendekatan psikologis diperoleh data bahwa para ayah dalam komunitas keluarga pekerja Rumah Sakit Abdul Manap di Kota Jambi belum sepenuhnya memahami arti penting Peran Ayah (Fathering) dalam pengasuhan anak usia dini, ditunjukkan dengan hasil wawancara 17 orang subyek diukur dengan Skala Sikap Ayah (Fathering Profile) mayoritas memberikan jawaban "sesekali"dan hasil skor yang diperoleh para subyek semua berada pada level "Average to Low" yaitu berada pada kisaran menengah cenderung rendah. Hasil penelitian dianalisa melalui pendapat para ahli, diperkuat penjelasan dalam Al-Qur'an dan Hadis Rasulullah SAW agar menjadi wacana baru bagi sumbangsih pendidikan anak usia dini di era 4.0 dimana orang tua dituntut mendidik anak sesuai dengan zamannya. Generasi Platinum (Gen Z) dengan orang tua Milenial yang berada dalam pusaran arus informasi bebas, berkarakter terbuka, butuh ruang bicara dan didengarkan. Para ayah membutuhkan wawasan dan ilmu untuk terlibat lebih banyak dalam pengasuhan. Praktek mencintai, melatih dan menjadi contoh yang berlangsung seumur hidup dapat diterapkan dengan meningkatkan intensitas dialog ayah dan anak.
\end{abstract}

Kata Kunci: Fathering; Pengasuhan; Anak Usia Dini

\title{
PENDAHULUAN
}

Haikal Hassan menuliskan dalam bukunya bahwa kesuksesan sebuah keluarga adalah ketika pasangan suami istri dapat secara bersama-sama melalui setiap dinamika dalam rumah tangga (Baras, 2020). Astrid Savitri (Savitri, 2019) berpendapat bahwa pembagian tugas dimana ayah sebagai pencari nafkah dan ibu mengurus rumah rasanya sudah tidak lagi banyak berlaku di zaman sekarang. Saat ini ayah dan ibu di sebagian besar keluarga berperan mencari nafkah demi memenuhi segala kebutuhan hidup keluarga. Komunikasi yang memegang peranan penting seringkali gagal diterapkan dalam rumah dimana ayah dan ibu sama-sama bekerja, hal tersebut dikarenakan orangtua merasa sulit meluangkan waktu untuk menjalin komunikasi yang baik. Kenyataan tersebut diperumit dengan fakta bahwasannya dewasa ini tak dapat dipungkiri bahwa Era 4.0 telah memberikan kebebasan akses informasi bagi anak-anak generasi platinum dan orang tua milenial. Kondisi tersebut membawa banyak keuntungan sekaligus keresahan yang memaksa orang tua berpikir keras untuk tetap menjaga anakanaknya dari pengaruh buruk dan mengembalikan para ayah dalam fitrah kepemimpinan dalam keluarga, sesuai dengan petunjuk Allah SWT dalam QS. AtTahrim ayat 6: 


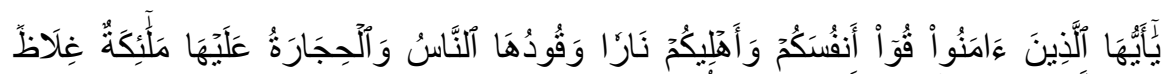

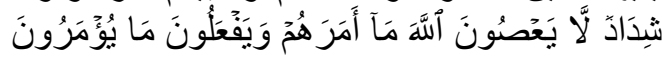

Yang artinya: "wahai orang-orang yang beriman, peliharalah dirimu dan keluargamu dari api neraka yang bahan bakarnya adalah manusia dan batu, penjaganya malaikat-malaikat yang kasar, dan keras, yang tidak durhaka kepada Allah terhadap apa yang Dia perintahkan kepada mereka dan selalu mengerjakan apa yang diperintahkan." (QS. At-Tahrim:6)

Dan sabda Rasulullah SAW yang berbunyi:

"Setiap diri dari kalian adalah pemimpin dan bertanggung jawab atas apa yang dia pimpin, seorang imam adalah pemimpin yang bertanggung jawab atas rakyatnya, seorang lelaki adalah pemimpin di keluarganya dan bertanggung jawab atas keluarganya, seorang wanita adalah pemimpin dirumah suaminya dan bertanggung jawab atas rumah suaminya, pembantu adalah pemimpin untuk harta tuannya dan bertanggung jawab atas harta tuannya."

Anak-anak ditakdirkan Allah lahir dalam sebuah keluarga dimana mereka tidak dapat memilih lingkungan tempat dia diasuh dan dibesarkan. Keluarga tempat dia dilahirkan akan memberikan pengaruh dan cerminan bagi anak dalam kehidupannya dimasa depan, dengan demikian menjadi tanggung jawab orang tua dengan segala upaya menyediakan lingkungan terbaik dan menghindarkan segala pengaruh buruk dalam proses pengasuhan. Petunjuk Al-Qur'an dan Hadis menjelaskan kedudukan seorang ayah dalam keluarga sebagai orang yang bertanggung jawab melindungi anggota keluarganya, istri dan anak-anaknya dari ancaman api neraka. Menurut Dr. Abdullah Nashih Ulwan (Ulwan, 2007), metode yang paling berpengaruh dan terbukti berhasil dalam mempersiapkan dan membentuk aspek moral, spiritual, dan etos sosial anak adalah keteladanan dari orang tua, maka sebagai pemimpin keluarga, keteladanan dari ayah menempati urutan yang pertama.

Sahabat Ali bin Abi Thablib pernah berkata "Didiklah anak-anakmu karena mereka akan hidup di zaman yang bukan zamanmu ini" dan Rasulullah SAW telah memperingatkan umatnya akan datangnya sebuah zaman yang dari hari kehari akan semakin buruk dan kian buruk dimana akan banyak tantangan berat menghadang kebenaran (Syarifuddin, 2004). Wulansari menjelaskan dalam bukunya bahwa setiap perubahan akan membawa rasa tidak nyaman, dan dalam proses penyesuaian disetiap perubahan zaman memberikan banyak tantangan untuk bertahan hidup, bergaul, menuntut ilmu, pengasuhan anak, serta segala tantangan lain yang muncul sebagai konsekuensi dari perubahan.(Wulansari, 2017). Orang tua memiliki fitrah pengasuhan untuk ingin melindungi anaknya dari ancaman era digital, namun tentu tidak ingin menghalangi potensi dari manfaat dari kemudahan yang ditawarkan oleh teknologi. Dan ayah sebagai pemimpin memiliki hak tertinggi dalam menetapkan kebijakan aturan dalam rumah tangga.

Parenting 4.0 melibatkan anak-anak usia dini yang lahir di generasi platinum dengan orang tua milenial yang cenderung menerapkan pola asuh demokratif (authoritative), dimana anak-anak diberi banyak kebebasan untuk 
memilih dan memutuskan dalam kehidupan mereka. Dengan demikian orang tua membutuhkan cara dan strategi tersendiri dalam pengasuhan di era 4.0 agar segalanya tidak menjadi lepas kendali. Orang tua dituntut mempelajari dan menerapkan berbagai strategi pengasuhan yang sesuai dengan perkembangan zaman, yang harus disusun bersama oleh ayah dan ibu, termasuk bila dalam kepengasuhan melibatkan orang lain seperti kakek, nenek, paman, bibi ataupun orang upahan agar visi dan misi keluarga berjalan satu tujuan. Hal ini sejalan dengan pendapat Stephanus Turibius Rahmat (Rahmat, 2018) yang mengungkapkan dalam jurnalnya bahwa pola asuh yang dibutuhkan pada era digital adalah pola asuh demokratis (authoritative) dikarenakan pola asuh ini berupaya membantu anak agar bersikap kritis terhadap pengaruh-pengaruh negative dampak digitalisasi. Orang tua demokratis membuka peluang berdialog, mendengar dan berbicara dalam membimbing anak menggunakan media digital untuk tujuan yang benar dan positif.

Rosnita (Rosnita, 2016) dalam tulisannya yang menyajikan pandangan Ibn Miskawaih tentang urgensi pembentukan akhlak anak sejak usia dini mengungkapkan bahwa seorang anak bisa menampilkan akhlak mulia ketika orang yang mengasuh dan mendidik mampu memberi lingkungan yang sehat secara moral, memahami kejiwaan anak, mengajari dan membentuk pola kebiasaan akhlak baik pada anak dengan memperhatikan karakteristik sifat anak, dimulai sejak usia dini. Membahas tentang urgensi pendidikan anak usia dini, Novan Ardy Wiyani (Wiyani, 2014) berpendapat bahwa salah satu faktor yang menjadi penyebab lemahnya sumber daya manusia (SDM) di Indonesia adalah akibat pengabaian terhadap penyelenggaraan Pendidikan Anak Usia Dini (PAUD). Sementara berbagai literatur telah menjelaskan bahwa usia lahir hingga delapan tahun merupakan masa keemasan dalam kehidupan anak dimana tingkat kepekaan otak terhadap segala rangsangan sedang berada pada puncaknya. Masa depan seorang anak ditentukan oleh seberapa optimal rangsangan atau stimulus eksternal dan internal diberikan pada anak di usia dini.

Perilaku pengasuhan ayah disebut dengan paternal behavior atau diistilahkan dengan pengasuhan paternal. Karakteristik perilaku pengasuhan ayah yang khas adalah berorientasi pada gerak dan bermain, membantu anak bereksplorasi dan menyukai tantangan, mengajarkan sikap asertif, kebijaksanaan, pengambilan keputusan, disiplin dan tegas, sifat maskulin bagi anak laki dan memberi role model pria dewasa bagi anak perempuan, ayah sebagai peletak dasar kemampuan intelektual, afeksi dan pendukung utama keberhasilan anak (Sundari \& Herdajani, 2013). Banyak pria merasa tidak siap menjalani peran ayah karena tidak pernah ataupun jarang melihat model yang demikian dimasa-masa sebelumnya, generasi-generasi sebelumnya memberikan porsi pengasuhan hampir menyeluruh pada sosok ibu (maternal). Pola pendidikan tradisional telah menempatkan laki-laki dan perempuan dalam wadah berbeda yang menjauhkan ayah dari fitrah pengasuhan anak. Pada masa penjajahan dan pra-kemerdekaan anak perempuan tidak mendapat pendidikan yang cukup hingga wawasan mereka hanya dipersiapkan pada urusan seputar dapur, kasur dan sumur (Husin, 2018). Tanggung jawab Pendidikan dan pengasuhan anak diberikan sepenuhnya pada ibu sementara tugas ayah hanya memenuhi kebutuhan finansial semata dengan bekerja keras. Pola pikir orang tua jaman dahulu itulah yang ditanamkan pada 
generasi-generasi selanjutnya hingga mulai disadari timbulnya dampak ketiadaan peran ayah dalam generasi terkini akibat pola asuh masa lalu.

Siti Fadjryana Fitroh (Fitroh, 2014) dalam jurnalnya menjelaskan definisi ketiadaan peran ayah maksudnya adalah ketidakhadiran secara fisik maupun psikologis dalam kehidupan anak. Dikenal dengan istilah fatherless, father absence, father loss atau father hunger. Ketiadaan peran ayah akan berdampak pada rendahnya harga diri (self-esteem) saat dewasa, perasaan marah (anger), malu (shame), kesepian (loneliness), kecemburuan (envy), dan kedukaan (grief), perasaan kehilangan yang sangat (lost), rendah control diri (self-control), tidak berani mengambil resiko (risk-taking), dan adanya kecenderungan neurotik akibat dorongan berbagai perasaan tidak nyaman secara mental (insecure). Akibatakibat psikologis yang timbul akan menjadi tekanan tersendiri yang membawa dampak pada penyimpangan perilaku dan perasaan tidak bermakna dalam hidup sebagai dampak stress berkepanjangan. Sedangkan Munjiat dalam jurnalnya menyatakan bahwa Fatherless dalam perspektif keislaman juga berdampak terhadap kesiapan seorang anak untuk menjadi abdan (hamba Allah) dan khalifah (pemimpin) akibat anak cenderung merasa minder, sulit beradaptasi, lambat kematangan emosionalnya, ragu-ragu dalam setiap keputusan dan cenderung lari dari permasalahan dimana segala persiapan tersebut hanya dapat dipenuhi melalui keterlibatan pengasuhan ayah sebagai pemimpin dan pendidik.

Cahyadi Takariawan (Takariawan, 2016), seorang penulis buku, konsultan pernikahan dan keluarga mengungkapkan fenomena yang terjadi akibat kurangnya wawasan tentang peran ayah, antara lain adalah minimnya kehadiran para ayah dalam undangan kegiatan pertemuan orang tua murid di sekolah, termasuk dalam acara pengambilan raport, seminar parenting maupun acara pengajian umum dengan tema pendidikan anak, mayoritas dihadiri oleh kaum ibu dengan dalih para ayah sibuk bekerja. Ironisnya jika diamati upaya para penyelenggara untuk mengadakan workshop parenting ataupun upaya sekolah mengadakan acara diluar jam kerja ataupun dihari libur dengan harapan orang tua bisa hadir secara lengkap juga tidak membuahkan hasil meningkatnya animo kehadiran para ayah. Peran serta ayah dalam pengasuhan seringkali ditampakkan dalam hal-hal yang terkait perlindungan fisik dan pemenuhan kebutuhan finansial seperti mengantar jemput sekolah, kursus dan memberikan uang jajan bagi anakanak. Namun demikian, ketidakhadiran ayah dalam momen-momen perkembangan anak menimbulkan dugaan bahwa ayah memahami peran dan bersedia berbagi tugas pengasuhan namun kurang memiliki cukup wawasan akan pentingnya peran ayah terlibat lebih dalam pada pemantauan aspek-aspek perkembangan dan penanaman nilai-nilai moral pada anak.

Carey Casey (Casey, 2009) menjelaskan istilah "Championship Fathering" sebagai sebuah peran dalam kehidupan seorang ayah yang akan berlangsung seumur hidup, dimana dalam prakteknya meliputi praktek mencintai, melatih dan menjadi contoh (role model). Penerapannya tentu berbeda pada saat anak-anak berusia dini dan anak remaja maupun kelak tumbuh dewasa, menikah dan akhirnya mereka melahirkan generasi baru sendiri, namun seorang ayah yang kelak menjadi kakek tetap akan dalam praktek peran ayah hingga akhir kehidupannya yang akan terus mencintai, melatih, dan menjadi teladan bagi anaknya. Para ayah membutuhkan wawasan dan ilmu agar proses mencintai, melatih dan menjadi teladan berlangsung dengan baik. 
Dialog dapat dijadikan sebagai media dalam melakukan proses loving, coaching, modeling dalam pengasuhan anak. Citra Permatasari (C. Permatasari, 2019) memberikan cara yang dianggap mudah dan murah meriah untuk dilakukan para ayah dalam pengasuhan namun memberikan dampak yang positif dalam mengisi kekosongan tanki cinta dalam proses loving dalam praktek Fathering, yaitu dengan meluangkan waktu, mendengarkan dengan sungguhsungguh, dan bersikap netral saat memberikan solusi permasalahan. Makna dialog yang sesungguhnya dalam Fathering yaitu coaching untuk diterapkan dalam pendidikan dan pengasuhan. Ida S. Widayanti (Widayanti, 2018) menjelaskan bahwa coaching dianggap tepat karena anak-anak memiliki sifat dasar tidak suka diperintah dan dilarang, melalui teknik coaching anak-anak merasa menjadi subjek karena dia diberi kepercayaan untuk membuat keputusan sendiri. Melalui teknik ini anak-anak juga akan merasa diterima dan dimengerti perasaannya, dan yang terakhir anak-anak tidak merasa dinasehati ataupun disalahkan. Bagaimana dialog antara ayah dan anak dilakukan dapat kita rujuk QS. Ash-Shaffat ayat 102 yang mengisahkan bagaimana Nabi Ibrahim meminta pendapat putranya Ismail AS saat datang perintah Allah untuk berkurban. Sebuah dialog penuh kasih sayang tanpa paksaan maupun ancaman, dilakukan dua arah tanpa arogansi dan superioritas dalam mencapai sebuah kesepakatan. Modeling dalam pengasuhan anak adalah bagaimana kita menjadi sosok yang dicintai dan diidolakan oleh anak-anak sehingga segala yang kita kerjakan akan ditiru oleh mereka. Bendri Jaisyurrahman (Jaisyurrahman, 2019) yang biasa disebut sebagai Fatherman dalam bukunya memberikan tiga jurus jitu membuat anak-anak jatuh cinta dan menjadikan ayahnya sebagai role model dalam hidup. Pertama, dengan seringkali memeluk ataupun memberikan sentuhan fisik pada anak-anak sejak usia dini agar menjadi sebuah hal nyaman yang rutin dilakukan dan kelak dirindukan, karena bila dilakukan saat mereka mulai beranjak remaja ataupun dewasa mereka akan merasa risih dan aneh yang justru berakibat anak mejauh karena merasa tidak nyaman. Kedua, ungkapkan cinta secara personal pada masing-masing anak, diikuti dengan memberikan kata maupun kode rahasia yang hanya dimiliki oleh mereka berdua, artinya setiap anak akan merasa memiliki kedekatan khusus yang membuat mereka merasa istimewa. Ketiga, banyak mendoakan anak secara terbuka agar anak mengetahui bahwasannya namanya selalu disebut ayah dalam doa-doanya, hal ini memberikan penguatan akidah pada anak sekaligus contoh teladan yang baik untuk melibatkan Allah dalam setiap sisi kehidupan.

Al-Qur'an banyak menggambarkan indahnya proses pendidikan dan pengasuhan anak yang dilakukan oleh ayah yang dilakukan melalui media "Dialog". Tesis karya Sarah Binti Halil memaparkan ragam dialog orang tua dengan anaknya yang tersebar dalam 9 surat. Terdapat 17 dialog yang diabadikan dalam Al-Qur'an, dimana 14 diantaranya adalah dialog antara ayah kepada anak, dan sebaliknya anak kepada ayah. Sedangkan 2 dialog lainnya adalah dialog antara ibu dan anak, dan 1 dialog antara orang tua pada anak (Zubaidi, 2018). Hal tersebut menunjukkan betapa tinggi nilai dialog antara ayah dan anak, Al-Qur'an menjelaskan lengkap dengan keragamannya, mulai bagaimana cara seorang ayah berdialog dengan putranya, putrinya, anak-anak dalam jumlah yang banyak, putra yang saleh maupun yang durhaka, cara anak menasehati ayah dan sebaliknya cara ayah berwasiat pada anak, cara ayah bermusyawarah pada anak- 
anaknya, cara ayah menyampaikan keputusan, cara ayah melarang anak, memberi perhatian, dan segala hikmah sudah terkandung didalam ayat suci AlQur'an yang memberikan wawasan bagi orang tua khususnya ayah dalam melaksanakan praktek pengasuhan.

Berangkat dari latar belakang diatas, penulis tertarik mengkaji lebih dalam tentang Fathering dalam pengasuhan anak usia dini, khususnya dalam komunita pekerja Rumah Sakit Abdul Manap di Kota Jambi. Tujuan dari penelitian ini yang paling utama adalah untuk menjawab dugaan bahwa para ayah kurang memahami pentingnya peran dalam pengasuhan anak usia dini. Sedangkan tujuan lainnya adalah untuk menambah wawasan penulis sekaligus memberikan wacana dan pengetahuan bagi orang tua secara umum dan ayah secara khusus tentang pentingnya optimalisasi pengasuhan anak usia dini.

\section{METODOLOGI}

Penelitian ini mengangkat kajian Fathering dan konsep pengasuhan anak oleh ayah dalam Al-Qur'an sehingga data primer yang dikaji mengacu pada teori tentang Fathering oleh Carey Casey dan firman-firman Allah dalam Al-Qur'an yang menjelaskan proses pendidikan dan pengasuhan anak melalui cara dialog. Data sekunder yang digunakan untuk mendukung dan menginterpretasi data primer seperti hadis-hadis Rasulullah SAW, perkataan para sahabat dan ulama, buku-buku parenting dan psikologi anak usia dini, pendapat para tokoh pendidikan anak yang akan memperkuat penjelasan makna ayat agar dapat dipraktekkan dalam kehidupan sehari-hari.

Metode penelitian yang digunakan adalah kualitatif deskriptif dengan pendekatan psikologis yang dilakukan langsung kepada subjek penelitian untuk memperoleh gambaran tentang praktek Fathering yang dilakukan dalam keluarga komunitas pekerja Rumah Sakit Abdul Manap di Kita Jambi. Penelitian difokuskan pada perawat, bidan dan dokter umum yang bertugas di ruang operasi. Proses analisis data dilakukan dengan mereduksi data, menyajikan, menarik kesimpulan, dan memverifikasi data. Uji keabsahan data ini menggunakan teknik trangulasi. Subyek penelitian berjumlah 17 orang, dimana dalam keluarga tersebut ayah dan ibu berperan sebagai pencari nafkah. Penelitian dilakukan di Rumah Sakit Abdul Manap kota Jambi dalam kegiatan Inhouse Training sebagai program yang rutin diadakan disana.

\section{HASIL DAN PEMBAHASAN \\ Fathering}

Fathering Profile yang diadaptasi dari buku "Championship Fathering" menjadi Skala Sikap Ayah yang digunakan dalam penelitian ini untuk melihat sejauh mana keterlibatan ayah dalam peran pengasuhan anak. Berdasarkan jawaban 17 orang subyek, hasil skor terhadap pertanyaan tentang seberapa intens melakukan kegiatan bersama anak-anak menunjukkan bahwa semua ayah masih berada pada level menengah kebawah. Dengan demikian disimpulkan bahwa praktek Fathering dalam keluarga kelompok pekerja Rumah Sakit Abdul Manap di Kota Jambi belum berlangsung optimal. Data dikuatkan dengan perolehan skor para ayah yang mayoritas berada dibawah rata-rata, menunjukkan bahwa praktek pengasuhan ayah belum menjadi fokus utama dalam keluarga. Kata Fathering dalam aplikasi ponsel pintar Oxford English Dictionary diartikan 
sebagai kegiatan "menjadi ayah" atau peran ayah dalam pengasuhan. Fathering biasa diterjemahkan kedalam status kehadiran ayah, dan keterlibatan ayah dalam peran pengasuhan (Flouri, 2005). Carey Casey (Casey, 2009) dalam bukunya yang berjudul "Championship Fathering" menjelaskan bahwa peran pengasuhan ayah terhadap anak merupakan proses loving, coaching, modelling yaitu mencintai, melatih dan memberikan teladan yang prakteknya akan berlangsung seumur hidup ayah. Lamb et al. (Lamb, 2010) mengemukakan keterlibatan peran ayah dalam pengasuhan meliputi tiga hal, pertama adalah Paternal Engagement yaitu pengalaman ayah berinteraksi langsung dan melakukan aktivitas bersama misalnya bermain, dan menyediakan waktu luang. Kedua, Paternal Accesibility yaitu kehadiran dan kesediaan ayah untuk anak secara fisik dan emosional. Ketiga, Paternal Responsibility yaitu sejauh mana ayah memahami dan memenuhi kebutuhan anak, termasuk memberikan nafkah dan ikut merancang masa depan anak. Formulasi tersebut memberikan gambaran ideal bagaimana seorang ayah dikatakan telah cukup berperan dalam kehidupan anak sekaligus memberikan harapan bagi cerahnya masa depan anak.

Widayanti (Widayanti, 2018) mengungkapkan bahwa University of Maryland School of Medicine, University of Illionis, dan University of Oxford telah melakukan beberapa kajian tentang keterlibatan ayah dalam pengasuhan. Disimpulkan dalam kajian tersebut bahwa peran ayah selain dilakukan oleh ayah kandung, bisa juga digantikan oleh ayah tiri, ayah adopsi, atau kakek, paman ataupun saudara lakilaki tertua. Hal tersebut sudah terbukti kebenarannya melalui jejak kehidupan tauladan umat muslim, yaitu Nabi Muhammad SAW. Beliau menjadi yatim sejak dilahirkan dan besar dibawah pengasuhan kakek dan pamannya. Dibawah pengasuhan kakek dan paman sebagai pengganti sosok ayah, Nabi Muhammad SAW dewasa telah menjadi sosok suami yang ideal dan ayah yang sempurna bagi istri-istri dan putra-putrinya. Allah SWT berfirman dalam QS. Al-Ahzaab ayat 21 sebagai bekal keimanan bagi seluruh umat muslim dalam meneladani setiap sikap dan perilaku Rasulullah (Baras, 2020).

Allah menjelaskan dalam Al-Qur'an QS. Al-Anbiya ayat 72-75 tentang penunjukkan Nabi Ibrahim, Nabi Luth, Nabi Ishak dan Nabi Ya'qub sebagai pemimpin umat karena empat hal penting. Pertama, mereka mengerjakan kebajikan sesuai petunjuk Allah. Kedua, mereka mendirikan shalat sebagai wujud hubungan dengan Allah setiap waktu. Ketiga, mereka menunaikan zakat sebagai wujud kesadaran sosial dalam hubungan kemasyarakatan. Keempat, mereka selalu mengembalikan segala persoalan dalam hidupnya kepada petunjuk Alqur'an dan Hadis. Demikianlah karakter-karakter kepemimpinan yang perlu dimiliki oleh seorang ayah telah Allah jelaskan melalui tauladan pada Nabi.

Gambaran sistematis peran pendidikan dan pengasuhan ayah kepada anak ada pada sosok Luqmanul Hakim, yang diabadikan melalui QS.Luqman dimana Allah 此 berfirman :

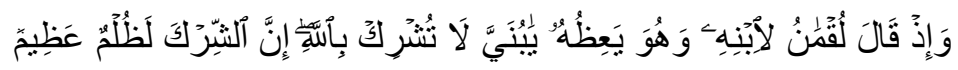

Yang artinya: "Dan (ingatlah) ketika Luqman berkata kepada anaknya, diwaktu ia memberi pelajaran kepadanya, 'Hai anakku, janganlah kamu mempersekutukan Allah, sesungguhnya mempersekutukan (Allah) adalah benar-benar kedzaliman yang besar." (QS.Luqman: 13). Wasiat Luqman kepada anaknya merupakan 
wasiat besar dan penting, yaitu memelihara akidah, memelihara tauhid, dan tidak menyekutukan Allah.

Pada temuan hasil penelitian berdasar respon 17 orang subyek didapati kuantitas ataupun tingkat kekerapan ayah berkegiatan dengan anak-anak terbanyak berada pada level "sesekali". Kegiatan yang "sering" dan "setiap kali" dilakukan para ayah bersama anak-anak lebih banyak adalah aktifitas bermain. Mayoritas para ayah menyatakan "tidak pernah" membacakan cerita untuk anakanak dan hanya sesekali melibatkan anak-anak dalam menemani ayah menyelesaikan pekerjaan. Namun demikian para ayah merasa "seringkali" atau setidaknya "seimbang" dalam hal meluangkan waktu untuk anak-anak dan merasa "setiap kali" bersenang-senang bersama anak

\section{Pengasuhan Anak Usia Dini}

Dinamika orang tua yang ayah dan ibu sama-sama berperan mencari nafkah dalam keluarga salah satunya adalah problematika membagi waktu. Data hasil penelitian 17 orang subyek menunjukkan bahwa mayoritas ayah menjawab "sesekali" terhadap pertanyaan yang menunjukkan intensitas keterlibatan ayah dalam praktek pengasuhan, dengan demikian Fathering dalam keluarga komunitas pekerja Rumah Sakit Abdul Manap belum maksimal. Praktek pengasuhan pada anak seringkali disebut dengan istilah Parenting. Penggunaan kata Parenting untuk aktivitas pengasuhan anak digunakan karena sampai saat ini belum ada padanan kata dalam Bahasa Indonesia yang tepat. Asti Musman (Musman, 2020) dalam bukunya menjelaskan makna Parenting sebagai suatu proses untuk meningkatkan dan mendukung perkembangan fisik, emosional, sosial, finansial, dan intelektual seorang anak sejak bayi hingga dewasa. Aplikasi Kamus Besar Bahasa Indonesia Edisi Kelima (KBBI V) menjelaskan dengan kata proses, cara, perbuatan asuh. Dengan demikian maka "Pengasuhan" atau Parenting adalah segala proses interaksi, kegiatan pengasuhan dan pendidikan dalam rangka membangun kematangan sosial anak sejak lahir hingga dewasa.

Pengasuhan anak dalam Islam diambil dari kata Hadhanah (mengasuh anak). Secara Bahasa, al-Hadhanah adalah mendidik dan mengurus anak-anak. Hadhanah secara harfiah adalah memasukkan sesuatu kedalam buaian, atau dekapan, karena pendidik dan pengurus harus senantiasa merapatkan diri disisi anak, dalam artian harus senantiasa membuat anak dekat dalam pengawasan. Seacar syariat Hadhanah diartikan merawat anak yang belum bisa mengurus urusannya secara mandiri, mengurus makanan, pakaian, tidur kebersihan, Kesehatan dan memberi perlindungan dari hal-hal yang bisa mencelakakan dan membahayakannya (Januar, 2018). Bila kaum wanita dalam keadaan tidak berhak atas hadhanah maka hak ini akan dikembalikan pada kaum laki-laki, karena mereka lebih mampu menjaga, melindungi, dan mewujudkan kebaikan anak-anak. Hadhanah anak adalah hak kedua orang tuanya manakala pernikahan diantara keduanya masih tegak. Jane B Brooks (Brooks, 2013) mendefinisikan pengasuhan sebagai sebuah proses yang merujuk pada serangkaian aksi dan interaksi yang dilakukan orang tua untuk mendukung perkembangan anak. Proses pengasuhan adalah hubungan dua arah yang saling mempengaruhi antara orang tua dan anak dalam sebuah lingkungan lengkap dengan budaya yang berlaku dimana anak dibesarkan.

Sebuah keluarga idealnya bertumpu pada dua figur, yaitu ayah dan ibu. Namun demikian, kenyataannya banyak disekeliling kita anak-anak yang kurang 
beruntung dihadapkan dalam kondisi perceraian orang tua, kematian orang tua atau bahkan ketidakhadiran figur ayah meski keduanya hadir lengkap secara fisik. Ketiadaan kedua orangtua memiliki pengaruh yang signifikan pada anak-anak, tetapi ketiadaan figur ayah cenderung memberikan efek yang lebih serius dalam mempengaruhi kehidupan anak-anak dimasa mendatang (Januar, 2018). Dalam melakukan praktek pengasuhan anak tentu saja orang tua dituntut memahami karakteristik anak usia dini yang berbeda-beda dan kadangkala tidak terukur dengan tingkat usia karena setia anak memiliki keunikan tersendiri satu dengan lainnya. Namun demikian, secara umum karakteristik anak usia dini adalah memiliki rasa ingin tahu yang besar, suka berfantasi dan berimajinasi, berpotensi mempelajari banyak hal, daya konsentrasi relatif pendek, egosentris tinggi, suka mencoba hal baru dan merupakan peniru ulung (Dacholfany \& Hasanah, 2018). Selain daripada itu hal terpenting dan paling menonjol dari ciri khas anak usia dini adalah mereka belajar melalui bermain. Berdasar data hasil penelitian, hanya 6 dari 17 subyek yang seringkali menghabiskan waktu bermain bersama anak-anak, 7 dari 17 subyek yang meluangkan banyak waktu bersama anak, dan 7 dari 17 orang yang bersenang-senang bersama anak. Hal ini memberikan gambaran bahwasannya para ayah membutuhkan wawasan lebih tentang pentingnya arti bermain bagi anak-anak.

Fadlillah (Fadlillah, 2017) mengutip pendapat Al-Ghazali yang mendefiniskan arti bermain adalah suatu yang sangat penting bagi anak, melarang anak bermain dapat mematikan hatinya, mengganggu kecerdasannya dan merusak irama hidupnya. Penjelasan lebih lanjut dikutip oleh Permatasari (D. C. Permatasari, 2017) bahwa Al-Ghazali juga menjelaskan bahwa pendidikan agama harus dimulai sejak anak masih dalam usia dini, karena pada usia tersebut anak sudah siap menerima ajaran agama atas dasar keimanan yang telah menjadi fitrahnya sejak lahir, meski pengajaran yang mereka dapat tidak membutuhkan penjelasan rinci dan dalil, maka pengajaran tentu harus disesuaikan dengan kapasitas usia. Menurut Rasulullah cara belajar sambil bermain, melakukan bimbingan dalam suasanya ramah, menyenangkan, riang gembira dan penuh kasih sayang adalah cara terbaik dalam pembentukan anak usia 0-6 tahun (Habibi, 2020). Diperkuat pendapat Freobel, bahwa bermain adalah aktivitas manusia yang paling murni pada level usia manapun, artinya bermain merupakan salah satu kebutuhan mutlak dalam kehidupan manusia, meski tentu saja bermain memiliki banyak penafsiran disesuaikan dengan berbagai konteks.

Tiga setengah dekade belakangan, lingkup kajian ilmiah mengalami perkembangan ditunjukkan dengan ribuan artikel profesional yang mengeksplorasi bagaimana kajian Fathering mempengaruhi perkembangan anak. Dengan demikian kajian tentang peran ayah dalam pengasuhan anak sekarang tidak lagi terasa asing untuk dijadikan bahan diskusi, meski pada kenyataannya Al-Qur'an dan Hadis Rasulullah sudah jauh lebih dahulu membahasnya sebelum banyak penelitian dilakukan. Banyaknya porsi dialog antara ayah dan anak dibandingkan dengan dialog antara ibu dan anak maupun dialog orang tua pada anak yaitu 14:2:1 menunjukkan bahwa porsi pengasuhan anak seharusnya lebih banyak dipegang oleh ayah, yang bila dalam pelaksanaannya terdapat kendala maka ayah tetap harus terlibat dalam pengawasan terhadap orang yang dipercaya untuk menggantikan tugas dan perannya. 
Hasil penelitian mendeskripsikan bahwa kegiatan yang "tidak pernah" dilakukan oleh mayoritas ayah dalam keluarga komunitas pekerja Rumah Sakit Abudl Manap Kota Jambi adalah membacakan cerita. Sedangkan mayoritas para ayah hanya "sesekali" menemani anak-anak menyelesaikan pekerjaan, "seimbang" dan "seringkali" meluangkan waktu bersama serta merasa "setiap kali" bersenang-senang bersama anak-anak. Bila merujuk pada praktek Fathering yang didefinisikan oleh Carey Casey (Casey, 2009) yang menyatakan "loving, coaching and modeling" yaitu mencintai, melatih dan memberikan teladan sebagai dasar modal seorang ayah untuk terlibat dalam pengasuhan, maka para ayah membutuhkan daftar sebagai panduan untuk melakukan kegiatan dalam memaknai keterlibatannya dalam pengasuhan. Daftar yang dapat digunakan para ayah diantaranya : 1) Sering diskusi bersama anak. Tidak menjadi masalah meski anak dianggap belum bisa memahami namun ayah perlu melakukan pembiasaan melakukan percakapan dengan anak. Melatih percakapan dengan anak sekaligus menjadi stimulus bagi anak usia dini yang belum bisa bicara dan memperbanyak kosakata bagi balita yang sudah mulai bisa bicara. 2) Melakukan banyak hal bersama. Biasakan diri untuk masuk kedalam "dunia anak-anak" dan biarkan mereka masuk dalam "dunia ayah." Libatkan anak-anak untuk membantu pekerjaan ayah sesuai dengan usia mereka dan terlibatlah membantu pekerjaan anak-anak, 3) Jadwalkan secara khusus waktu bersama anak. Membuat janji khusus dengan anak membuat mereka merasa spesial, merasa dicintai dan menumbuhkan rasa percaya diri, 4) Melatih ketrampilan anak dalam kehidupan. Mengajari anak naik sepeda, berenang, memanah, dan berkuda, dan olahraga. Libatkan mereka dalam mengatur jadwal kegiatan harian dan berikan mereka tugas dan tanggung jawab sesuai usianya, 5) Berperan aktif dalam pendidikan anak. Memiliki visi misi pendidikan bersama pasangan dan membicarakannya bersama guru disekolah akan memberikan banyak informasi baik dan buruk tentang anak kita akan memudahkan kita dalam mengontrol, 6)Terlibat dekat dalam kehidupan anak. Mengetahui nama-nama teman dekat anak, siapa orang tuanya, makanan dan minuman kesukaan anak, warna dan gaya baju yang disukai akan membuat anak merasa sangat dipahami, 7) Selalu gembira bersama. Menciptakan momen-momen bahagia baik didalam segala keadaan, suka maupun duka. Melatih kepekaan dan kepedulian dengan saling menghibur dalam segala suasana.

Generasi Z adalah mereka yang lahir diantara tahun 1996-2010, generasi selanjutnya disebut Generasi Platinum, keduanya menjadi generasi kelompok usia pertama yang mengonsumsi teknologi internet sejak usia sangat muda. Karakter Gen Z adalah berpikir terbuka dan berpikir praktis, ekspresif dan eksploratif selaras dengan perkembangan zaman dimana saat ini semua hal mengarah pada proses digitalisasi. Anak-anak zaman ini sudah terbiasa menggunakan gawai untuk berbagai kebutuhan (Karmadewi et al., 2017). R.D. Asti (Asti, 2019) menjelaskan dalam bukunya bahwa Era 4.0 identik dengan segala hal yang berkaitan dengan teknologi digital, dengan demikian orang tua milenial juga perlu mengetahui teknik pengasuhan bagi generasi digital, diadaptasikan pada gaya pengasuhan secara umum, yaitu demokratis, permisif, dan otoriter. Orang tua digital yang demokratis menyediakan teknologi dan aplikasi terbaru bagi anakanaknya yang dapat diartikan sebagai izin untuk berselancar di internet, namum mereka akan menjelaskan sebaik mungkin batas-batas keamanan yang berkaitan 
dengan layar dan menerapkan aturan yang disepakati dalam online, orang tua melakukan kompromi dan diskusi dengan anak. Orang tua digital yang permisif menyediakan teknologi dan aplikasi terbaru bagi anak-anaknya dan memberikan kebebasan penuh tanpa kendali orang tua. Orang tua otoriter mungkin menyediakan teknologi dan aplikasi terbaru bagi anak-anaknya dengan peraturan yang sangat terikat dan terbatas, atau mungkin dengan tegas mereka sama sekali tidak mengijinkan anak-anaknya tersentuh teknologi.

Studi eksplorasi tentang peran ayah dalam pengasuhan anak usia dini yang dilakukan oleh Sri Muliati Abdullah (Abdullah, 2010) menyimpulkan berdasarkan data yang diperoleh bahwa ayah telah menyadari bahwa tugas pengasuhan merupakan tugas bersama, namun demikian beberapa kendala yang berhasil diungkapkan adalah para ayah merasa mudah bosan, tidak sabar, cepat marah, terlalu lelah bekerja, tidak tau cara menstimulus dan mengajari anak, dan tidak tau apa yang harus dilakukan saat anak tantrum dan berulah. Kendala-kendala tersebut memberikan gambaran bahwasannya keterlibatan ayah dalam pengasuhan kurang optimal. Senada dengan penelitian tersebut, penelitian di Aceh mengungkapkan bahwa ayah memiliki kesadaran akan peran dalam pengasuhan anak, namun terkendala tuntutan sebagai pencari nafkah (Maisyarah et al., 2017). Sementara Dodi Mawardi dan Dicky Ardiansyah Budiman (Karmadewi et al., 2017) mengungkap bahwa dalam laporan yang dimuat dalam Journal of Applied Developmental Psychology, terungkap bahwa kegiatan mendongeng sebelum tidur dapat meningkatkan tabungan kosakata yang dimiliki anak dan kelak berdampak terhadap prestasi akademiknya. Penelitian ini berhasil mengungkap kontribusi unik dari peran ayah yang diharapkan dapat menjawab kendala para ayah untuk terlibat dalam pengasuhan sekaligus bisa memberikan ide-ide penelitian baru dimasa mendatang.

\section{SIMPULAN}

Berdasarkan hasil penelitian yang menyimpulkan bahwasannya praktek pengasuhan yang dilakukan ayah kepada anak atau yang disebut dengan Fathering pada keluarga komunitas pekerja Rumah Sakit Abdul Manap Kota Jambi belum optimal dan masih dapat ditingkatkan menjadi lebih maksimal. Para ayah membutuhkan lebih banyak wawasan dan informasi untuk memahami urgensi Fathering dalam pengasuhan anak usia dini. Rujukan praktek pengasuhan yang ideal dapat dilihat bahwa pendapat para ahli, petunjuk Al-qur'an dan Hadis Rasulullah 䔝, maupun hasil-hasil yang diungkap dari berbagai penelitian terdahulu menunjukkan sebuah kesepakatan bahwasannya "dialog" menjadi jawaban bagi para ayah untuk mengoptimalisasikan keterlibatannya pada praktek Fathering dalam pengasuhan anak usia dini. Dialog dapat diaplikasikan para ayah dalam berbagai bentuk kegiatan bersama anak, baik saat sedang mendongeng, sedang bermain bersama, sedang mengantar-jemput sekolah, dan berbagai momen ayah bersama anak. Dialog terbukti menjadi petunjuk dalam kitab suci Al-Qur'an yang menjadi pedoman hidup umat muslim. Dialog juga sesuai dengan teori Fathering dimana dalam mencintai, melatih dan menjadi tauladan membutuhkan praktek dialog didalamnya. Dialog juga dianggap sesuai dengan karakteristik Gen Z di Era 4.0 yang membutuhkan banyak ruang untuk bicara dan didengar.Dengan demikian dapat disimpulkan bahwa "dialog" menjadi jawaban bagi berbagai permasalahan keterlibatan ayah dalam peran pengasuhan. 
Hasil penelitian ini hanya merupakan kajian awal dari apa yang akan diteliti lebih lanjut. Peneliti ingin menggali lebih dalam pada setiap kepingan tema dalam penelitian ini pada beragam lokasi dan subyek yang berbeda. Pesan moral yang ingin penulis sampaikan melalui penelitian ini adalah urgensi mengembalikan para ayah kepada fitrah pengasuhan pada anak, utamanya sejak anak-anak berusia dini. Penulis membuka diri atas saran dan masukan yang akan diberikan oleh peneliti lain demi tercapainya kesempurnaan sebuah teori baru. Penelitian ini berupaya menyatukan berbagai disiplin ilmu dalam satu visi dan misi membentuk generasi terbaik dimasa depan.

\section{DAFTAR PUSTAKA}

Al-Qur'an. (2013). Hijaz The Practice. Syaamil Qur'an.

Abdullah, S. M. (2010). Studi Eksplorasi Tentang Peran Ayah Dalam Pengasuhan Anak Usia Dini. Spirits, 1(1), 1-9.

Asti, R. D. (2019). Parenting 4.0 Mendidik Anak Di Era Digital. Caesar Media Pustaka.

Baras, H. H. (2020). Menjadi Suami \& Ayah Hebat (1st ed.). Gema Insani.

Brooks, J. (2013). The Process Of Parenting (A. Lonn (ed.); 9th ed.). Michael Sugarman.

Casey, C. (2009). Championship Fathering. Tyndale House.

Dacholfany, M. I., \& Hasanah, U. (2018). Pendidikan Anak Usia Dini Menurut Konsep Islam (Budiyadi (ed.); 1st ed.). Amzah.

Fadlillah, M. (2017). Bermain dan Permainan Anak Usia Dini (1st ed.). Prenadamedia Group.

Fitroh, S. F. (2014). Dampak Fatherless terhadap Prestasi Belajar Anak. Jurnal PG-PAUD Trunojoyo: Jurnal Pendidikan Dan Pembelajaran Anak Usia Dini, 6(1), 76-146.

Flouri, E. (2005). Fathering \& Child Outcomes. John Wiley \& Sons Ltd.

Habibi, M. (2020). Konsep Pendidikan Anak Usia Dini Menurut Psikologi Islam. Deepublish.

Husin. (2018). Fathering Adversity Management. Al-Qalam, 12(2), 1-24. https://doi.org/http://dx.doi.org/10.35931/aq.v0i0.73

Jaisyurrahman, B. (2019). Fatherman (. Tim Langkah Kita (ed.)).

Januar, M. I. (2018). Hadhanah. Al Azhar Fresh Zone Publishing.

Karmadewi, K. I., Gufron, M., Maisyafriana, Kholidin, Aryogo, P., Bharata, D. A., \& Fadilah, H. (2017). Ayah Peran Vitalnya Dalam Pengasuhan (D. Mawardi \& D. A. Budiman (eds.)). Yayasan Bhakti Suratto.

Lamb, M. E. (2010). The Role Of Father In Child Development (5th ed.). John Wiley \& Sons Ltd.

Maisyarah, Ahmad, A., \& Bahrun. (2017). Peran Ayah pada Pengasuhan Anak Usia Dini dalam Keluarga di Kecamatan Darussalam, Kabupaten Aceh Besar. Jurnal IImiah Mahasiswa Pendidikan Guru Anak Usia Dini, 2(1), 50-61.

Musman, A. (2020). Seni Mendidik Anak Di Era 4.0. Penerbit Psikologi Corner.

Permatasari, C. (2019). Kiat Ampuh Menjadi Ayah Idaman. Unicorn Publishing.

Permatasari, D. C. (2017). Ayah Hebat= Anak Hebat. Psikologi Corner.

Perpustakaan Nasional. (2013). Al-Qur'an, Hijaz The Practice. Syaamil Qur'an.

Rahmat, S. T. (2018). The Effective Parenting Patterns to Educate Children in The 
Digital Era. Journal Education and Culture Missio, 10(2), 137-273. https://repasitory.stikipsantupaulus.ac.id/122/1/Artikel-jurnal-missio

Rosnita, R. (2016). Pembentukan Akhlak Anak Usia Dini Menurut Ibn Miskawaih. MIQOT: Jurnal IImu-IImu Keislaman, 37(2), 396-414. https://doi.org/10.30821/miqot.v37i2.89

Savitri, A. (2019). Bijak Mendidik Anak Di Era Milenial. Briliant.

Sundari, A. R., \& Herdajani, F. (2013). Dampak Fatherlesness Terhadap Perkembangan Psikologis Anak. Prosiding Seminar Nasional Parenting 2013, 53(9), 1689-1699.

Syarifuddin, A. (2004). Mendidik Anak Membaca, Menulis dan Mencintai AlQur'an. Gema Insani.

Takariawan, C. (2016). Ayah Harus Banyak Dialog Dengan Anak. https:/www.kompasiana.com/pakcah/583e9f77d07a614511c2fa26/ayahharus-banyak-dialog-dengan-anak

Ulwan, A. N. (2007). Pendidikan Anak Dalam Islam (Adib \& A. M. Asrori (eds.)). Pustaka Amani.

Widayanti, I. S. (2018). Sebuah Pekerjaan Bernama Ayah (D. Kusmayadi (ed.)). PT. Arga Tilanta.

Wiyani, N. A. (2014). Psikologi Perkembangan Anak Usia Dini. Gava Media.

Wulansari, N. M. D. (2017). Didiklah Anak Sesuai Zamannya. Visimedia.

Zubaidi, S. (2018). Filsafat Pendidikan dalam al-Qur'an: Dari Penciptaan Manusia ke Edukasi Komunikasi. Tsaqafah, 14(1), 73. https://doi.org/10.21111/tsaqafah.v14i1.2297 